\title{
On some new or poorly-known species of the millipede family Polydesmidae from southern China (Diplopoda: Polydesmida)
}

\section{О несколыких новых и малоизвестных видах диплопод семейства Polydesmidae из Южного Китая (Diplopoda: Polydesmida)}

\author{
Sergei I. Golovatch ${ }^{1} \&$ Jean-Jacques Geoffroy ${ }^{2}$, \\ С.И. Головач ${ }^{1}$, Ж.-ЖК. Жоффруа ${ }^{2}$
}

\footnotetext{
${ }^{1}$ Институт проблем экологии и эволюции РАН, Ленинский пр-т, 33, Москва 119071, Россия.

${ }^{1}$ Institute for Problems of Ecology and Evolution, Russian Academy of Sciences, Leninsky pr. 33, Moscow 119071 Russia.

${ }^{2}$ Национальный музей естественной истории, Париж, Франция.

2 Muséum national d'Histoire naturelle, Département Ecologie \& Gestion de la Biodiversité, UMR 7204 CESCO CNRS-MNHN-UPMC, Brunoy, France.
}

KEY WORDS: Diplopoda, Polydesmidae, taxonomy, new species, cave, China.

КЛЮЧЕВЫЕ СЛОВА: Diplopoda, Polydesmidae, таксономия, новый вид, пещера, Китай.

ABSTRACT. Several collections of Polydesmidae millipedes from China, mainly cavernicolous, contain not only two known, but also five new species: Glenniea blanca sp.n., G. lagredae sp.n. and Epanerchodus lipsae sp.n. from Sichuan, as well as Pacidesmus trifidus sp.n. and P. bifidus sp.n. from Guangxi. Their distributions are mapped and discussed. A key is presented to all three species of Glenniea Turk, 1945 currently known to occur in China.

РЕЗЮМЕ. Несколько коллекций диплопод семейства Polydesmidae из Китая, в основном пещерных, содержат не только два известных, но и пять новых видов: Glenniea blanca sp.n., G. lagredae sp.n. и Epanerchodus lipsae sp.n. из Сычуани, а также Pacidesmus trifidus sp.n. и P. bifidus sp.n. из Гуаньси. Закартировано и обсуждается их распространение. Дан ключ для всех трёх видов рода Glenniea Turk, 1945, ныне известных из Китая.

\section{Introduction}

The large, basically Holarctic millipede family Polydesmidae is quite well represented in the fauna of continental China: so far at least 16 species of the highly prolific East and central Asian genus Epanerchodus Attems, 1901, including several presumed troglobites [Golovatch, 2014a, b], six species of the small genus Pacidesmus Golovatch, 1991, all likely troglobites, in contrast to the sole, and type, species known from a high-mountain forest in northern Thailand [Golovatch et al., 2010], a single species of the great amphi-Palaearctic genus Polydesmus Latreille, 1802 [Golovatch, 1991], and a single, epigean species of the small, basically Himalayan genus Glenniea Turk, 1945 [Golovatch et al., 2012]. All cavernicolous polydesmids in
China are thereby confined to the karst massifs covering the southern parts of the country.

The present paper puts on record a few more collections of Polydesmidae, mainly cavernicolous, deriving from several karst regions of southern China and amassed at the Muséum national d'Histoire naturelle, Paris, France (MNHN). Most of the relevant localities are referred to in due detail in Lips [2005, 2009]. Altogether, two known and five new species have been revealed (Map 1).

\section{Material}

Most of the material treated below was taken in southern China by Josiane Lips (Villeurbanne, France) and/or her collaborators, as well as by Louis Deharveng and Anne Bedos (MNHN) and/or their collaborators. One sample was kindly provided by Arthur Clarke (Tasmania, Australia). The material is largely housed in MNHN, with only a few samples shared with the collection of the Zoological Museum, State University of Moscow, Moscow, Russia (ZMUM), as indicated below.

Taxonomic part

Glenniea prima Golovatch, Liu, Li et Geoffroy, 2012 Map 1.

MATERIAL. $1 \sigma^{7}$ (MNHN JC 362), China, Guangxi Prov., Chongzuo, Longzhou Xian, Shanglong Xiang, Lenglei, Nonggang Forest ( $=$ Nature Reserve), karst, $106.964835^{\circ} \mathrm{E}, 22.467175^{\circ} \mathrm{N}$, litter, Berlese extraction, 7.03.2005, leg. L. Deharveng \& A. Bedos (CHIgx05-052); 1 ○ (MNHN JC 362), same locality, 7.03.2005, leg. L. Deharveng \& A. Bedos (CHIgx05-066).

REMARKS. The above samples actually represent strict topotypes of this species, the sole congener of the small, mostly Himalayan genus Glenniea Turk, 1945 hitherto reported from China [Golovatch et al., 2012]. At the moment, 


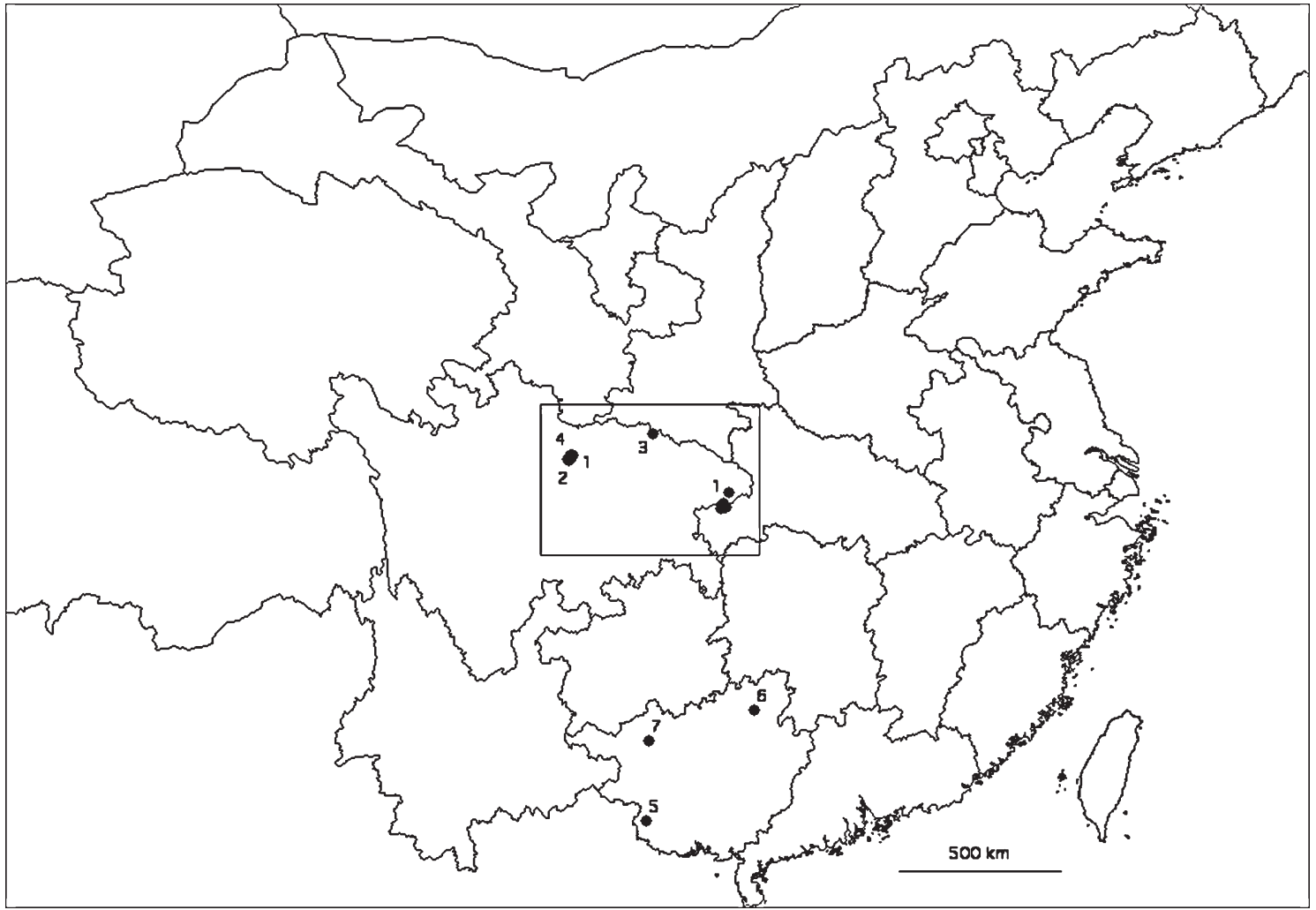

Map 1. General distribution of the species contained in the new collections from southern China. 1 - Epanerchodus varius Geoffroy et Golovatch, 2004; 2 - Epanerchodus lipsae sp.n.; 3 - Glenniea blanca sp.n.; 4 - Glenniea lagredae sp.n.; 5 - Glenniea prima Golovatch, Liu, Li et Geoffroy, 2012; 6 - Pacidesmus trifidus sp.n.; 7 - Pacidesmus bifidus sp.n.

Карта 1. Общее распространение видов, содержавшихся в новых сборах из Южного Китая. 1 - Epanerchodus varius Geoffroy et Golovatch, 2004; 2 - Epanerchodus lipsae sp.n.; 3 - Glenniea blanca sp.n.; 4 - Glenniea lagredae sp.n.; 5 - Glenniea prima Golovatch, Liu, Li et Geoffroy, 2012; 6 - Pacidesmus trifidus sp.n.; 7 - Pacidesmus bifidus sp.n.

this genus contains five species, all keyed, in the Himalayas of India (Kumaon), Nepal and Bhutan [Golovatch, 1988], plus the epigean G. prima in Guangxi, China. A further two new species of this genus are described below, this time both cavernicolous from Sichuan.

The topotypes fully agree with the original description [Golovatch et al., 2012], but both are a little larger than the holotype: ca $8 \mathrm{~mm}$ long, 0.65 and $0.8 \mathrm{~mm}$ wide on midbody pro- and metazonae, respectively.

\section{Glenniea blanca Golovatch et Geoffroy sp.n.} Figs 1-4, Map 1.

HOLOTYPE $0^{7}$ (MNHN JC 349), China, Sichuan Prov., Tong Jian County, Cave Lou Fang Dong (= Grotte de la Maison), $107^{\circ} 10.81 \mathrm{E}, 32^{\circ} 25.77 \mathrm{~N}, 600 \mathrm{~m}, 11.08 .2004$, leg. J. Lips (No 1532).

NAME. To emphasize the animal being entirely pallid.

DIAGNOSIS. Differs from congeners by several troglomorphic features such as the long antennae and legs, coupled with the presence of a falcate exomere, a short solenomere and a unipartite endomere. See also Key below.

DESCRIPTION. Length ca $16 \mathrm{~mm}$, width of pro- and metazonae 1.35 and $2.0 \mathrm{~mm}$, respectively. Coloration in alcohol uniformly pallid (Figs 1-2). Body with 20 segments. Tegument mainly poorly shining, texture very delicately alveolate. Head very densely pilose nearly throughout, with squarish genae. Antennae long and only slightly clavate due to highest antennomere 6 (height measured from the lower to the higher edge) (Fig. 2), slightly projecting behind segment 3 dorsally $\left(\sigma^{7}\right)$; antennomere 3 longest, ca 1.3 times as long as subequal antennomeres $4-6 ; 5^{\text {th }}$ and $6^{\text {th }}$ each with a small, compact, distodorsal group of bacilliform sensilla; antennomere 7 with a minute dorsoparabasal cone and a distodorsal group of microscopic sensilla.

In width, collum $=$ head $<$ segment $2<3=4<5=16$, thereafter body gradually tapering towards telson (Fig. 1). Paraterga rather strongly developed, set high (at about upper $1 / 4$ of body height), starting from collum; paraterga mostly slightly upturned above a very faintly convex dorsum, drawn clearly forward only on metatergum 2. Collum transversely oblong-oval, with two strong lateral incisions on each side. Caudolateral corner of postcollum paraterga sharp and dentiform, mostly moderately acutangular $\left(\mathrm{ca} 80^{\circ}\right)$ and lying within rear tergal margin, clearly extending beyond the margin only in segments 18 and 19; caudal margin of paraterga largely slightly concave, their front margin forming small shoulders, subrectangular. All poreless segments with five, all pore-bearing ones with six, strong, setigerous incisions/ teeth at lateral margin, sometimes with minute additional denticles (Figs 1-2). Pore formula normal, ozopores evident, dorsal, located at base of $4^{\text {th }}$ larger marginal indentation. Metatergal sculpture typical, well-developed, with three transverse rows of $3+3$ polygonal bosses with setiferous knobs or short and low crests (Figs 1-2). Sulcus between front and middle rows of setae a little deeper than that between middle and caudal rows. Tergal setae short (ca 1/6 the length of 


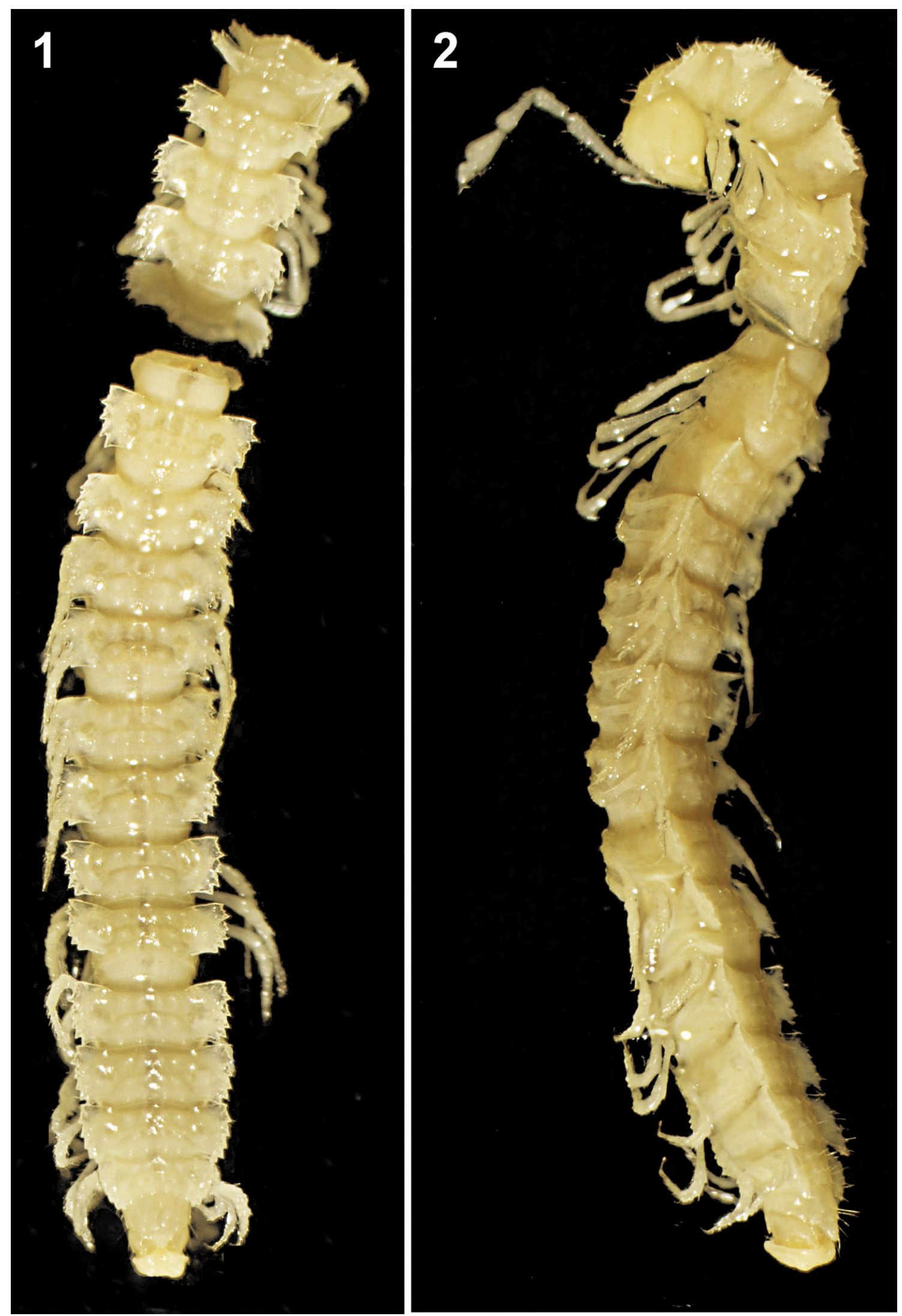

Figs 1-2. Glenniea blanca sp.n., holotype, habitus: 1 - dorsal view; 2 - lateral view. Photographs by A. Kirejtshuk, taken not to scale. Рис. 1-2. Glenniea blanca sp.n., голотип, внешний вид: 1 - сверху; 2 - сбоку. Фотографии А. Кирейчука, без масштаба. 
metatergite), simple, mostly retained. Stricture between proand metazonae rather wide, shallow and smooth. Limbus very thin, microdenticulate. Pleurosternal carinae absent. Epiproct rather short, conical, pre-apical lateral papillae small. Hypoproct subtrapeziform; caudal, paramedian, setiferous papillae small and well-separated.

Sterna without modifications, very poorly setose, crossimpressions rather deep. Legs long and slender, ca 2.0 times as long as body height (Figs 1-2), femora and tarsi longest and subequal in length, prefemora and femora faintly rugulose, sphaerotrichomes or other modified setae absent (Fig. 4).

Gonopods (Fig. 3) complex, in situ held parallel to each other; coxae strongly fused medially at base, micropapillate laterally, each coxa carrying a strong digitiform projection and a strong seta distodorsally. Telopodite only slightly curved caudally, rather stout, prefemoral (= densely setose) portion about half as long as telopodite; seminal groove running mesally only over basal half of prefemorite, more distally to recurve laterad and pass neatly between a subfalcate, simple exomere (ex) and a massive, elaborate endomere (en), the latter being beset with small setae parabasally on lateral face and armed with numerous, strong, sometimes curved spines in a caudomesally directed apical half. Seminal groove terminating on a small, but distinct, stump-shaped solenomere (sl) supplied with a small accessory chamber at base.

REMARKS. Due to the especially long and slender antennae and legs, as well as clearly upturned paraterga, this species seems to be a troglobite, the first presumably true cavernicolous congener to be encountered. Moreover, the unusually large size (ca $16 \mathrm{~mm}$ ) may well represent a case of "cave gigantism".

\section{Glenniea lagredae Golovatch et Geoffroy sp.n.}

Figs 5-8, Map 1.

HOLOTYPE $O^{7}$ (MNHN JC 350). China, Sichuan Prov., Beichuan County, Cave Yuan Dong (= La grotte du Rocher), $104^{\circ}$ 40.099E, 31 ${ }^{\circ} 53.738 \mathrm{~N}, 1510 \mathrm{~m}, 18.08 .2004$, leg. J. Lips (No. 1583),

PARATYPES: 4 OPO, 3 juv. (MNHN JC 350), same data, together with holotype; $10^{\top}, 1$ juv. (MNHN JC 350), Sichuan Prov., Hua Jiao Ling County, Cave Zhang Jia Yan Kou Keng, 10440.456E, $31^{\circ} 54.06 \mathrm{~N}, 1360 \mathrm{~m}, 1.08 .2009$, leg. J. Lips (No. 4124).

NAME. Dedicated to the memory of Mélissa Lagrede who died in an accident inside a cave during the 2009 expedition.

DIAGNOSIS. Differs from congeners by several troglomorphic features such as the long antennae and legs, coupled
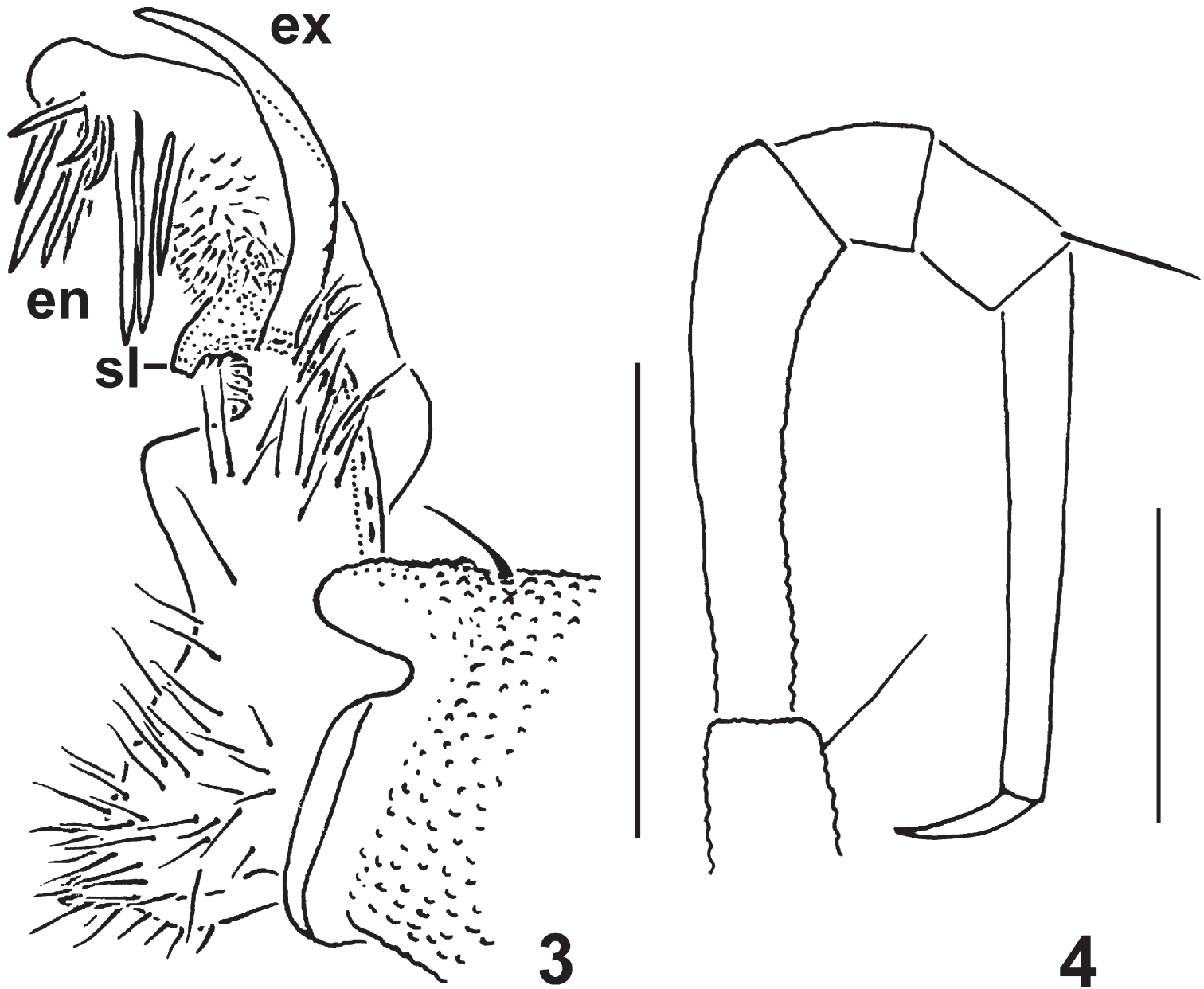

Figs 3-4. Glenniea blanca sp.n., holotype: 3 - left gonopod, lateral view; 4 - leg 9, lateral view; scale bars: $0.3 \mathrm{~mm}(3)$; $0.5 \mathrm{~mm}$ (4). Designations of gonopod structures in text.

Рис. 3-4. Glenniea blanca sp.n., голотип: 3 - левый гонопод, сбоку; 4 - нога 9, сбоку. масштаб: 0,3 мм (3); 0,5 мм (4). Обозначения частей гонопода в тексте. 
with the absence of an exomere, a solenomere and an evident accessory seminal chamber. See also Key below.

DESCRIPTION. Length of holotype ca $8 \mathrm{~mm}$, width of midbody pro- and metazonae 0.7 and $1.1 \mathrm{~mm}$, respectively; length of adult paratypes ca $7\left(\sigma^{7}\right)$ or 8-9 $\mathrm{mm}(++)$, width of their pro- and metazonae 0.6 and $1.0 \mathrm{~mm}\left(\sigma^{7}\right)$ or 0.75 and $1.0-1.1 \mathrm{~mm}(+)$, respectively. Coloration in alcohol uniformly pallid (Figs 5-6).
All characters as in $G$. blanca sp.n., except as follows. Antennae a little shorter, projecting behind only until midway of segment $3\left(\sigma^{7}\right)$ or $2(+)$ when stretched dorsally.

In width, collum $<$ head $<$ segment $2<3<4<5=16$, thereafter body gradually tapering towards telson (Fig. 5). Paraterga rather strongly $\left(\sigma^{7}\right)$ or poorly $(+)$ developed, set high (at about upper $1 / 4$ of body height), starting from collum; paraterga mostly subhorizontal, always placed be-

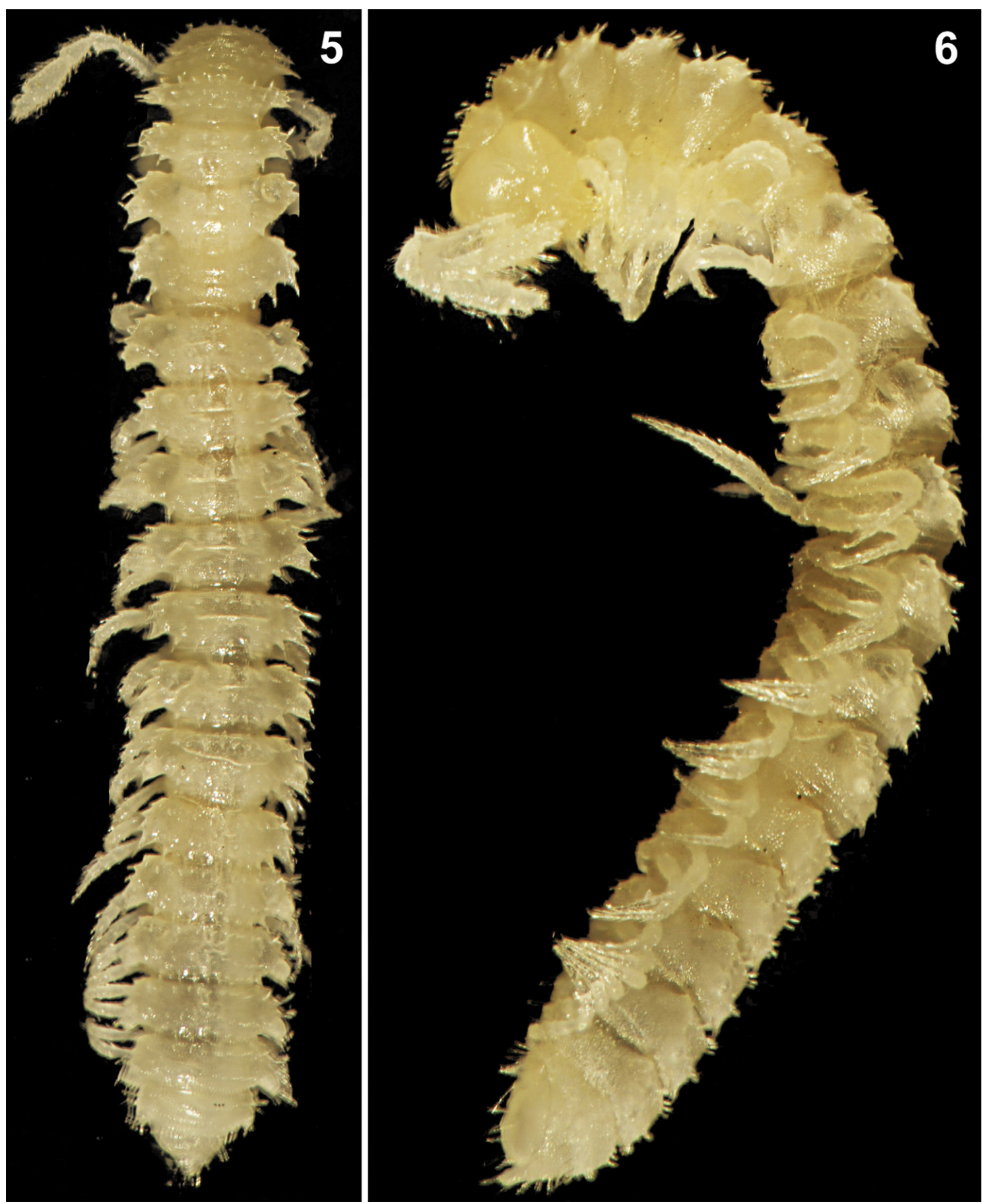

Figs 5-6. Glenniea lagredae sp.n., O paratype, habitus: 5 - dorsal view; 6 - lateral view. Photographs by A. Kirejtshuk, taken not to scale.

Рис. 5-6. Glenniea lagredae sp.n., О7 паратип, внешний вид: 1 - сверху; 2 - сбоку. Фотографии А. Кирейчука, без масштаба. 
low a fairly convex dorsum, slightly drawn forward only on metatergum 2. Collum transversely oblong-oval, with two rather small lateral incisions on each side. Caudolateral corner of postcollum paraterga sharp and dentiform, mostly clearly acutangular (ca $60^{\circ}$ ) and lying within rear tergal margin, well extending beyond the margin only in segments 17-19; caudal margin of paraterga largely well-concave and supplied with a strong setigerous tooth at base, their front margin forming small shoulders, mostly obtusangular (ca $\left.100^{\circ}\right)$. All poreless segments with four, all pore-bearing ones with five, strong, setigerous incisions/teeth at lateral margin (regardless of caudal tooth at base of paraterga) (Figs 5-6). Pore formula normal, ozopores evident, dorsal, located at base of penultimate larger marginal tooth. Metatergal sculpture typical, well-developed, with three transverse rows of mostly $4+4$ setiferous bosses/knobs (Figs 5-6). Sulcus between front and middle rows of setae a little deeper than that between middle and caudal rows. Tergal setae short (ca 1/5-1/6 the length of metatergite), simple, mostly retained.

Sterna without modifications, very poorly setose, crossimpressions rather deep. Legs rather long and slender, ca 1.7$1.8\left(\bigcirc^{7}\right)$ or 1.3-1.4 times ( + , juv.) as long as body height (Figs $5-6,8)$, tarsi longest, only slightly longer than femora, telopodites micropapillate and with sparse, but evident sphaerotrichomes ventrally (Fig. 8).

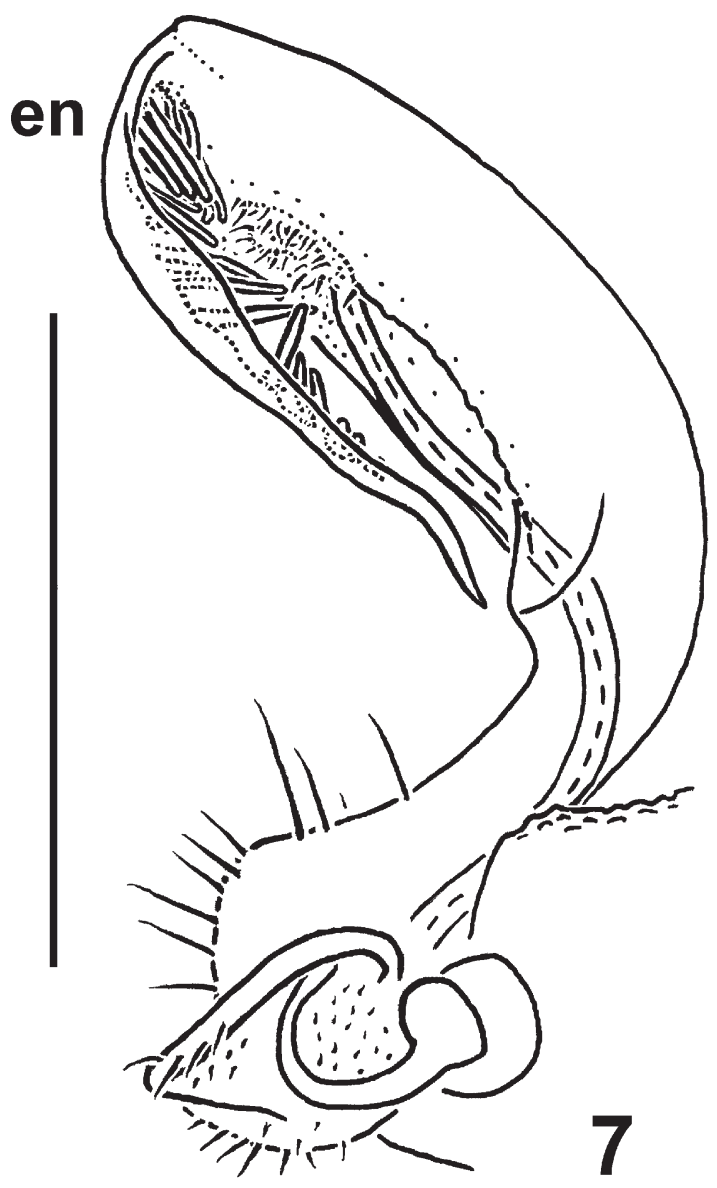

Gonopods (Fig. 7) relatively simple, in situ held nearly parallel to each other, only distal thirds of telopodites turned slightly mesally. Telopodite subfalcate, clearly curved caudally, rather slender, prefemoral (= densely setose) portion short, only about $1 / 5$ as long as telopodite; seminal groove running entirely mesally, terminating on a distinct hairy pulvillus; neither an exomere nor a solenomere, nor an evident accessory seminal chamber; endomere (en) very slender, acuminate, strongly curved, in distal $1 / 3$ beset with numerous, mostly strong, sometimes curved spines or bacilli.

REMARKS. Based on certain troglomorphic characters, such as the unpigmented tegument and the clearly elongated antennae and legs in the $\sigma^{7}$, this new species may also prove to represent a troglobite. It is likewise rather large compared to the Himalayan congeners which are all less than $6 \mathrm{~mm}$ in length. However, given the similarly unpigmented and large G. prima, which has never been encountered in caves, the ecological status of G. lagredae sp.n. is still to be confirmed.

Both Cave Yuan Dong and Cave Zhang Jia Yan Kou Keng also contain Epanerchodus lipsae sp.n., another presumed troglobite (see below).

Since the Himalayan species of Glenniea have long been keyed [Golovatch, 1988], below is a key to all three congeners currently known to occur in China alone:

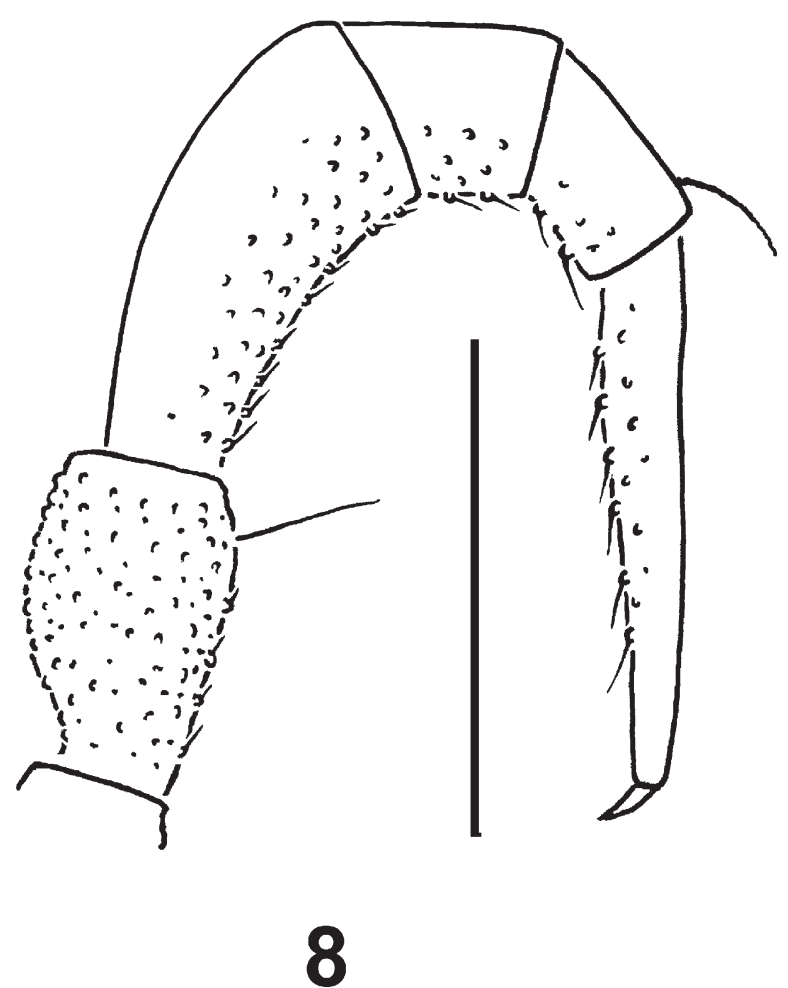

Figs 7-8. Glenniea lagredae sp.n., holotype: 3 - left gonopod, lateral view; 4 - leg 9, lateral view; scale bars - $0.3 \mathrm{~mm}$. Designations of gonopod structures in text.

Рис. 7-8. Glenniea lagredae sp.n., голотип. 3 - левый гонопод, сбоку; 4 - нога 9, сбоку; масштаб - 0,3 мм. Обозначения частей гонопода в тексте. 

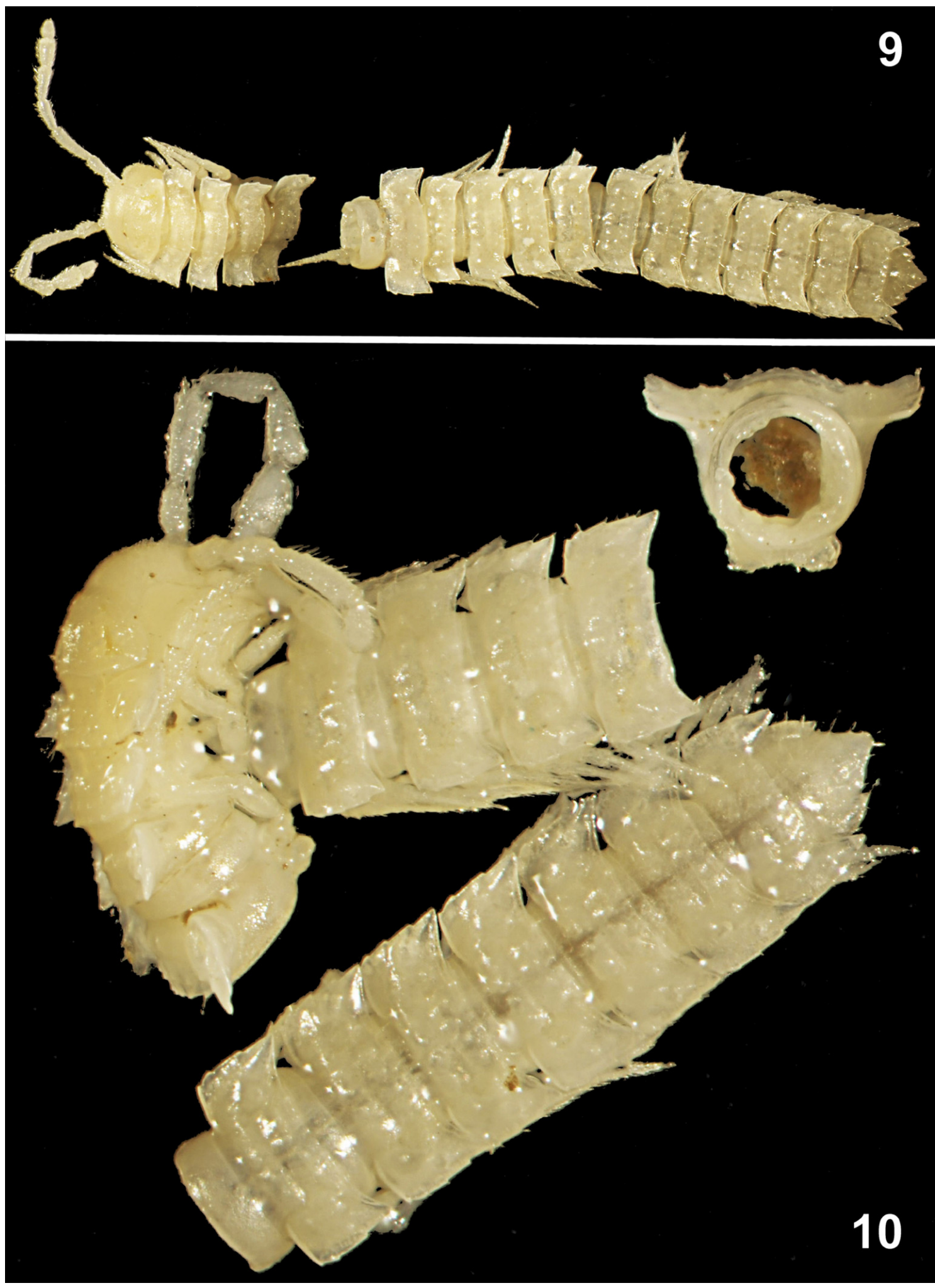

Figs 9-10. Pacidesmus trifidus sp.n., holotype, habitus: 9 - dorsal view; 10 - mixed view. Photographs by A. Kirejtshuk, taken not to scale.

Рис. 9-10. Pacidesmus trifidus sp.n., голотип, внешний вид: 9 - сверху; 10 - смешанно. Фотографии А. Кирейчука, без масштаба. 
1(2) Body much larger: length ca $16 \mathrm{~mm}$, width $2.0 \mathrm{~mm}$. Poreless paraterga with five, pore-bearing ones with six, strong, lateral, setigerous incisions/teeth (Figs 1-2). Gonopod bipartite, but stout, only slightly curved caudad (Fig. 3). G. blanca sp.n.

2(1) Body much smaller: length only ca $7 \mathrm{~mm}$, width $\leq 1.0$ $\mathrm{mm}$. Poreless paraterga with 3 or 4, pore-bearing ones with 4 or 5 , strong, lateral, setigerous incisions/teeth. Gonopod strongly curved, subfalcate and strongly elongate, bi- or unipartite.

3(4) Poreless paraterga with three, pore-bearing ones with four strong, lateral, setigerous incisions/teeth. Only $\sigma^{7}$ tarsi with sphaerotrichomes. Gonopod strongly bipartite, not only endomere, but also exomere being armed with numerous teeth. Forest litter in Guangxi. ...... G. prima

4(3) Poreless paraterga with four, pore-bearing ones with five, strong, lateral, setigerous incisions/teeth (Figs 5-6). Entire $\sigma^{7}$ telopodites with sphaerotrichomes ventrally (Fig. 8). Gonopod strongly unipartite, an exomere absent (Fig. 7). Caves in Sichuan. G. lagredae sp.n.

\section{Pacidesmus trifidus Golovatch et Geoffroy sp.n.} Figs 9-11, Map 2.

HOLOTYPE ơ (MNHN JC 351), China, Guangxi Prov., Guilin County, Grotte des Squelettes, $110^{\circ} 22 \mathrm{E}, 25^{\circ} 29 \mathrm{~N}, 22.07 .1992$, leg. J. Lips (B1-4).

PARATYPES: 2 우 (MNHN JC 351), same data, together with holotype.

NAME. To emphasize the trifid gonopod telopodite.

DIAGNOSIS. Differs from congeners by the presence of a small exomere and a trifid endomere.

DESCRIPTION. Length of holotype ca $9 \mathrm{~mm}$, width of pro- and metazonae 0.7 and $1.2 \mathrm{~mm}$, respectively; length of + paratypes ca 8-9 mm, width of pro- and metazonae 0.9 1.0 and $1.5-1.6 \mathrm{~mm}$, respectively. Coloration in alcohol uniformly pallid (Figs 9-10). Body with 20 segments. Tegument mainly poorly shining, texture very delicately alveolate. Head very densely pilose nearly throughout, with squarish genae. Antennae very long and only slightly clavate due to highest antennomere 6 (height measured from the lower to the higher edge) (Fig. 9), projecting behind segment $4\left(\mathrm{O}^{7}\right)$ or $3(+)$ when stretched dorsally; antennomere 3 longest, ca 1.3 times as long as subequal antennomeres $4-6 ; 5^{\text {th }}$ and $6^{\text {th }}$ each with a small, compact, distodorsal group of bacilliform sensilla; antennomere 7 with a minute dorsoparabasal cone and a distodorsal group of microscopic sensilla.

In width, collum $<$ head $<$ segment $3=4<2<5=17$, thereafter body rather quickly tapering towards telson (Figs 9-10). Paraterga rather strongly developed, set high (at about upper $1 / 4$ of body height), starting from collum; paraterga mostly slightly upturned above $\left(\sigma^{7}\right)$ or held subhorizontal to () a faintly convex dorsum, drawn clearly forward only on metatergum 2. Collum transversely oblong-oval, with one faint lateral incision on each side in front of a narrowly rounded caudal corner. Caudolateral corner of postcollum paraterga sharp, dentiform, increasingly acutangular and drawn behind rear tergal margin, especially strongly extending beyond the margin in segment 18; caudal margin of paraterga largely slightly concave, their front margin forming evident shoulders, subrectangular. All poreless segments with three, all pore-bearing ones with four, faint, setigerous incisions/teeth at lateral margin (Figs 9-10). Pore formula normal, ozopores evident, dorsal, located at base of penultimate marginal indentation. Metatergal sculpture typical, poorly-deve-

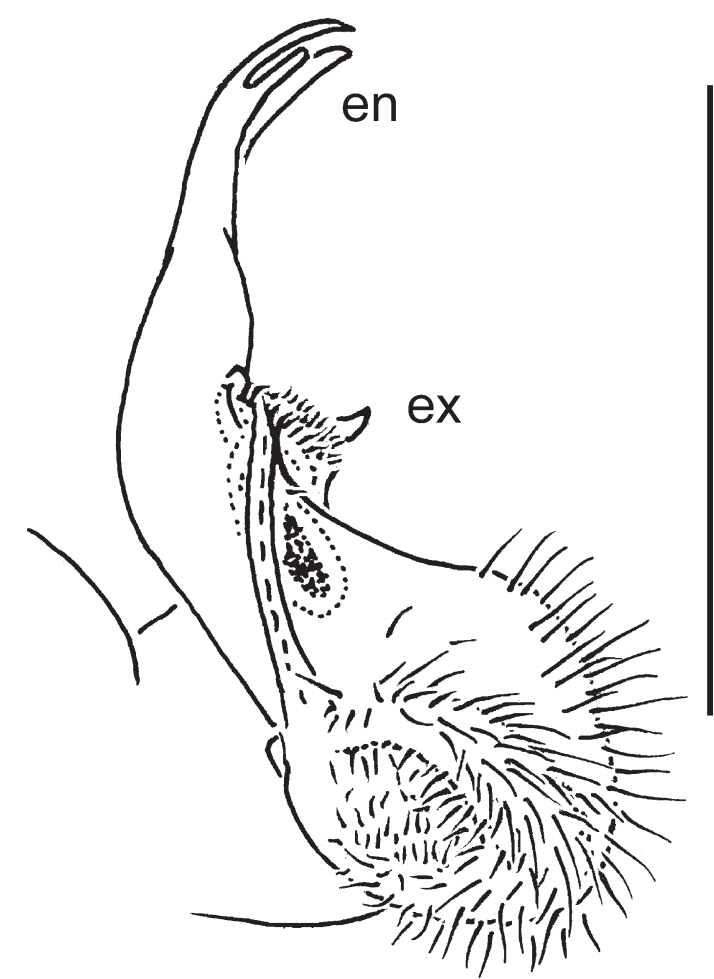

Fig. 11. Pacidesmus trifidus sp.n., holotype, left gonopod, mesal view. Scale bar: $0.3 \mathrm{~mm}$. Designations of gonopod structures in text.

Рис. 11. Pacidesmus trifidus sp.n., голотип, левый гонопод, изнутри. Масштаб: 0,3 мм. Обозначения частей гонопода в тексте.

loped, with three transverse rows of $3+3$ polygonal bosses with setiferous knobs (Figs 9-10). Sulcus between front and middle rows of setae a little deeper than that between middle and caudal rows. Tergal setae very short (usually ca $1 / 7-1 / 8$ the length of metatergite), simple, mostly retained. Stricture between pro- and metazonae rather wide, shallow and smooth. Limbus very thin, microdenticulate. Pleurosternal carinae absent. Epiproct rather short, conical, pre-apical lateral papillae evident. Hypoproct subtrapeziform; caudal, paramedian, setiferous papillae strong and well-separated.

Sterna without modifications, very poorly setose, crossimpressions shallow. Legs rather long and slender, ca 1.8-1.9 $\left(\mathrm{O}^{7}\right)$ or 1.5-1.6 (+) times as long as body height (Figs 9-10), tarsi being longest; sphaerotrichomes or other modified setae absent.

Gonopods (Fig. 11) simple, in situ held parallel to each other; coxae strongly fused medially at base, micropapillate laterally, each coxa carrying a strong seta distodorsally. Telopodite only slightly curved caudally, rather stout, prefemoral (= densely setose) portion about $1 / 3$ as long as telopodite, the latter's endomere (en) being clearly trifid; seminal groove running entirely mesally to terminate inside an evident accessory seminal chamber opening up on a strong hairy pulvillus located near a small lateral prong (= exomere, ex)

REMARKS. Due to the long and slender antennae and legs, as well as clearly upturned paraterga, like all Chinese congeners [Golovatch et al., 2010], this species seems to be a troglobite. 


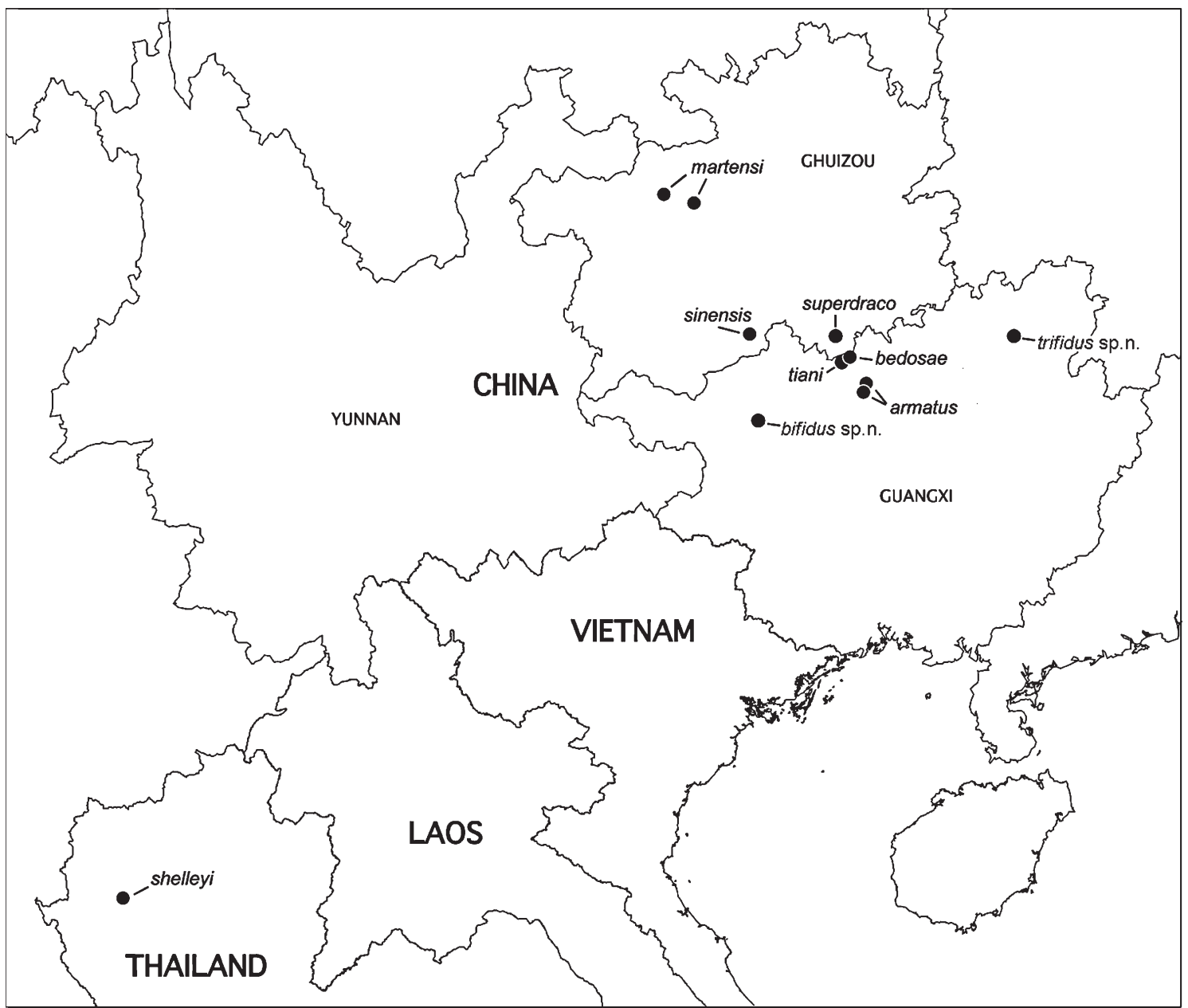

Map 2. Distribution of the known species of the genus Pacidesmus.

Карта 2. Распространение известных видов рода Pacidesmus.

\section{Pacidesmus bifidus Golovatch et Geoffroy sp.n.} Figs 12-16, Map 2.

HOLOTYPE $0^{7}$ (MNHN JC 352), China, Guangxi Prov., Cave Hengli Xin Dong near Fengshan (Fengshan Xian), $50 \mathrm{~m}$ deep, $107.043083^{\circ} \mathrm{E}, 24.521056^{\circ} \mathrm{N}, 5.11 .2005$, leg. A. Clarke (1105-37).

NAME. To emphasize the bifid gonopod telopodite.

DIAGNOSIS. Differs from congeners by the absence of an exomere, coupled with a narrowly and deeply bifid endomere. The new species seems to be especially similar to P. tiani Golovatch, Geoffroy \& Mauriès, 2010, another troglobite from northern Guangxi (Map 2), sharing a large body, very long legs and antennae, as well as a missing exomere and a bifid endomere, but the apex of the latter in P. bifidus sp.n. is split far more deeply while the paraterga are considerably narrower.

DESCRIPTION. Length ca $25 \mathrm{~mm}$, width of pro- and metazonae 1.8 and $2.7 \mathrm{~mm}$, respectively $\left(\sigma^{7}\right)$. Coloration in alcohol uniformly pallid (Figs 12-15).

All characters as in P. trifidus sp.n., except as follows.

Antennae very long, but projecting only behind segment 3 when stretched dorsally.

In width, head $<$ collum $<$ segment $3=4<2<5=16$, thereafter body gradually tapering towards telson (Figs $12-$
15). Paraterga strongly developed, set high (at about upper $1 / 4$ of body height), starting from collum; paraterga mostly slightly upturned above a faintly convex dorsum, drawn clearly forward only on metatergum 2. Caudolateral corner of postcollum paraterga sharp, dentiform, increasingly acutangular and drawn behind rear tergal margin, especially strongly extending beyond the margin in segments 18 and 19; caudal margin of paraterga largely slightly concave, their front margin mostly regularly convex. Tergal setae very short, largely abraded.

Legs very long and slender, ca 2.2-2.3 times as long as body height ( $\mathrm{O}^{7}$ ) (Figs 12-15).

Gonopods (Fig. 16) very simple, in situ held parallel to each other. Telopodite suberect, rather slender, prefemoral (= densely setose) portion nearly half as long as telopodite, the latter's endomere being clearly, deeply and narrowly bifid; seminal groove running mostly mesally to recurve laterad before entering inside a small, but evident accessory seminal chamber opening up on a modest hairy pulvillus; an exomere absent.

REMARKS. Due to the long and slender antennae and legs, as well as clearly upturned paraterga, like all Chinese congeners [Golovatch et al., 2010], this species seems to be a troglobite as well. 


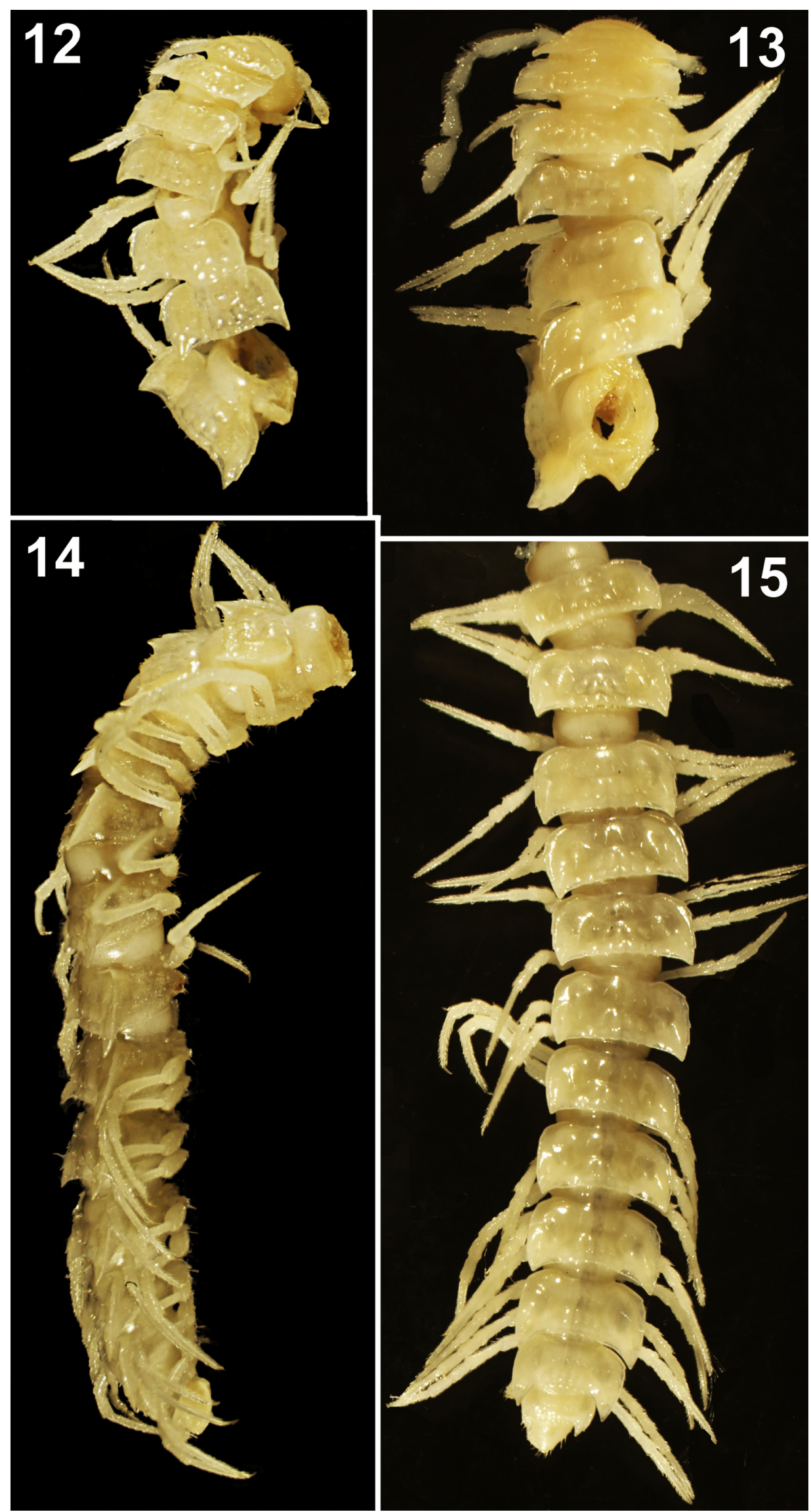




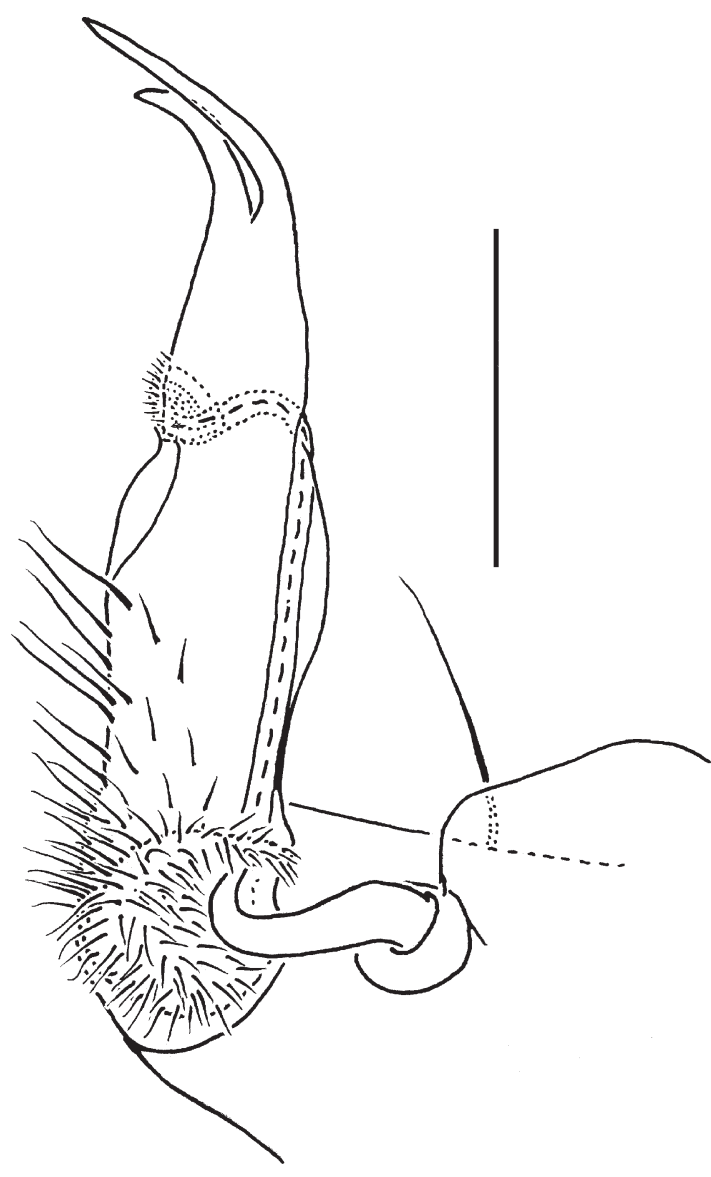

Fig. 16. Pacidesmus bifidus sp.n., holotype, right gonopod, mesal view. Scale bar: $0.3 \mathrm{~mm}$.

Рис. 16. Pacidesmus bifidus sp.n., голотип, правый гонопод, изнутри. Масштаб: 0,3 мм.

The genus Pacidesmus Golovatch, 1991 has hitherto been known from one species occurring on the forested summit of Mt Doi Inthanon, northern Thailand, as well as from further six, all presumably troglobitic, species in caves of Guizhou and Guangxi provinces, southern China [Golovatch et al., 2010]. The addition of another two new, also likely troglobitic congeners from Guangxi only slightly extends the range of Pacidesmus in the northern parts of that province (Map 2).

\section{Epanerchodus varius (Geoffroy et Golovatch, 2004) Map 3.}

MATERIAL. 1 O $^{\top}$ (MNHN JC 363), China, Hubei Prov., Banqiao County, Cave Chuan Dong $\mathrm{Zi}$ (= Grotte Chaude et Froide), $1400 \mathrm{~m}$, main gallery before siphon, $109^{\circ} 29.54 \mathrm{E}, 30^{\circ} 54.78 \mathrm{~N}$ 1.08.2006, leg. J. Lips (No. 2193); 1 + $10^{7}$ juv. (MNHN JC 363), same county, Cave Couronne d'épines $1,109^{\circ} 19.32 \mathrm{E}, 30^{\circ} 36.73 \mathrm{~N}$ 4.08.1999, leg. J. Lips (No. 384); 2 O $^{\top} \mathrm{O}^{7}, 6$ O+, 2 juv. (MNHN JC $363)$, same county, Cave Xiao Dong, $109^{\circ} 15.727 \mathrm{E}, 30^{\circ} 35.513 \mathrm{~N}$, ca 1480 m, 3.08.2006, leg. J. Lips (No. 2225); $10^{7}, 2$ ㅇ (MNHN JC
363), same cave, 3.08.2006, leg. J. Lips (No. 2234); $10^{7}, 3$ 우 (MNHN JC 363), same county, Cave Shuan Tian Keng (= Gouffre des Jumeaux du ciel), $109^{\circ} 15.272 \mathrm{E}, 30^{\circ} 35.388 \mathrm{~N}$, ca $1490 \mathrm{~m}$, 4.08.2006, leg. J.-M. Briffon (No. 2250); $1 \mathrm{O}^{7}, 5$ 우, 4 juv. (MNHN JC 363), same county, Grotte Haute de la Montagne, $109^{\circ} 15.923 \mathrm{E}$, $30^{\circ} 34.657 \mathrm{~N}, 1800 \mathrm{~m}, 5.08 .2006$, leg. J.-M. Verdet (No. 2254); 1 ๙", $^{\prime}$, 4 oᄋ, 7 juv. (MNHN JC 363), same county, Grotte de Kemaku, $109^{\circ} 15.316 \mathrm{E}, 30^{\circ} 34.577 \mathrm{~N}, 1705 \mathrm{~m}, 5.08 .2006$, leg. J. Lips (No. 2267); $10^{7}, 1$ ( (MNHN JC 363), $10^{7}$ (ZMUM 02357), same cave, 5.08.2006, leg. J. Lips (No. 2274); $10^{7}$ (MNHN JC 363), same cave, 7.08.2006, leg. Y. Schalk (No. 2290); 1 +, 1 juv. (MNHN JC 363), same county, Cave Da Tien Keng (= Le Grand Puits), $109^{\circ} 15.582 \mathrm{E}$, $30^{\circ} 34.777 \mathrm{~N}$, ca $1705 \mathrm{~m}, 8.08 .2006$, leg. J. Lips (No. 2307); $20^{7}, 6$ juv. (MNHN JC 363), same county, King's Lake Cave to Dolphin Cave (= Grotte du Dauphin), $109^{\circ} 16.815 \mathrm{E}, 30^{\circ} 32.606 \mathrm{~N}$, ca $1490 \mathrm{~m}$, 10.08.2006, leg. F. Rinaldi (No. 2332); 2 O $^{7} \sigma^{7}, 6$ 우 (MNHN JC 363), same county, Cave Feng Dong 2 (= La grotte du Vent No. 2), $109^{\circ} 16.803 \mathrm{E}, 30^{\circ} 36.741 \mathrm{~N}, 1540 \mathrm{~m}, 11.08 .2006$, leg. J.-M. Verdet (No. 2336); 1 juv. (MNHN JC 363), same county, Cave Yi Nu de Qiao Dong (= Résurgence Pont Emporté), $109^{\circ} 14.17 \mathrm{E}, 30^{\circ} 30.233 \mathrm{~N}$, $1230 \mathrm{~m}, 11.08 .2006$, leg. J. Lips (No. 2342); $1 \mathrm{O}^{\top}, 3$ 우 (MNHN JC 363), same county, Cave Tie He (= Résurgence de Tie He), $109^{\circ} 15.590 \mathrm{E}, 30^{\circ} 37.390 \mathrm{~N}$; ca $1370 \mathrm{~m}, 11.08 .2006$, leg. J. Lips (No. 2346); 1 + 1 juv. (MNHN JC 363), same county, Grotte de la Bouche de la Grenouille (= Grotte du Têtard) \& Cave Ha Ma Zui Dong (= Kedu Dong), $109^{\circ} 15.81 \mathrm{E}, 30^{\circ} 32.42 \mathrm{~N}, 1600 \mathrm{~m}, 6.08 .2009$, leg. J. Lips (No. 4135); $1 \mathrm{O}^{7}$ (MNHN JC 363), same county, Cave Baxian Dong (= Grotte du $8^{\mathrm{e}}$ Ciel), main gallery and crossing, $109^{\circ} 16.625 \mathrm{E}, 30^{\circ} 32.005 \mathrm{~N}, 1870 \mathrm{~m}, 7.08 .2009$, leg. A. Geneau \& M. Lagrede (No. 4157); 3 juv. (MNHN JC 363), same cave, 8.08.2009, leg. J. Lips (No. 4170); 5 ○ $^{7} \sigma^{7}, 1$, 4 juv. (MNHN JC 363), Cave Tu He Tu Feng Tian Keng (= Gouffre Mélissa), $109^{\circ} 15.374 \mathrm{E}, 30^{\circ} 34.688 \mathrm{~N}, 1710 \mathrm{~m}, 9.08 .2009$, leg. J. Lips (No. 4179); 1 우 (MNHN JC 363), Sichuan Prov., Beichuan County, Buddha Cave (a touristic cave) (= Grotte du Bouddha de Kuang Shan), main entrance, $104^{\circ} 41.836 \mathrm{E}, 31^{\circ} 50.122 \mathrm{~N}$, ca $580 \mathrm{~m}$, 16.08.2006, leg. J. Lips (No. 2380); 7 우우, 2 우 fragments, 3 juv. (MNHN JC 363), same county, Cave Niu Jiao Dong (= Grotte des Cornes de la Vache), $104^{\circ} 41.413 \mathrm{E}, 31^{\circ} 49.851 \mathrm{~N}, 580 \mathrm{~m}, 16.08 .2006$, leg. J. Lips (No. 2392); 1 ㅇ (MNHN JC 353), Xin Long County, Grotte des Trois Yeux (= Faux Trois Yeux), $1600 \mathrm{~m}, 109^{\circ} 22.54 \mathrm{E}$, $30^{\circ} 33.53 \mathrm{~N}, 29.07 .2004$, leg. J. Lips (No. 1446).

REMARKS. Most of the above samples actually contain near-topotypes of this species hitherto known solely from several caves in Hubei and Sichuan provinces, China [Geoffroy \& Golovatch, 2004; Golovatch et al., 2007]. Only one sample, the $\sigma^{7}$ from Cave Chuan Dong $\mathrm{Zi}$, represents a strict topotype.

The distribution of E. varius appears to be highly disjunct (Map 3), divided between the eastern cluster of caves, near the border between Hubei and Sichuan provinces and the western cluster, situated in north-central Sichuan. The latter karst cluster is mostly populated by the quite similar, but even more strongly troglomorphic, E. lipsae sp.n., although the two are allopatric, never being found in the same cave.

The only reasonable explanation for the unusually strong disjunction of $E$. varius that comes to mind is that the numerous karsts extending across Sichuan are still too poorly prospected, leaving the possibility that E. varius occurs within them. In any event, E. varius is remarkably widespread for a truly troglobitic diplopod species. Only future explorations can shed additional light on its true ecological status and distribution.

Figs 12-15. Pacidesmus bifidus sp.n., holotype: 12-13 — anterior part of body; 14-15 - posterior part of body; 12 — subdorsal view; 13,15 - dorsal view; 14 - lateral view. Photographs by A. Kirejtshuk, taken not to scale.

Рис. 12-15. Pacidesmus bifidus sp.n., голотип, 12-13 — передняя часть тела; 14-15 — задняя часть тела; 12 — почти сверху; 14 - сбоку; 13, 15 - сверху. Фотографии А. Кирейчука, без масштаба. 


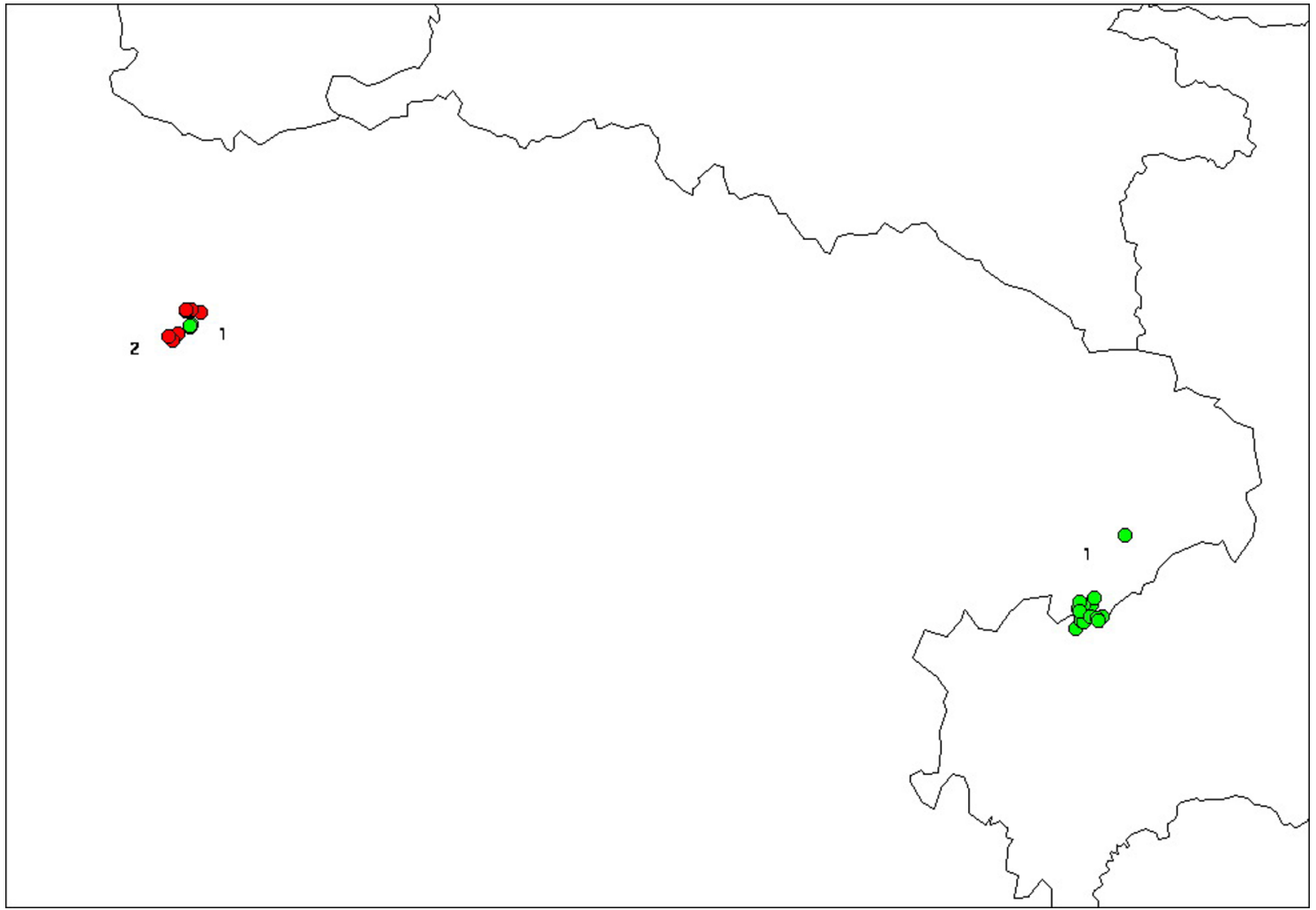

Map 3. Detailed distributions of Epanerchodus varius (1) and Epanerchodus lipsae sp.n. (2), corresponding to the frame shown on Map 1. Карта 3. Детальное распространение Epanerchodus varius (1) и Epanerchodus lipsae sp.n. (2), соответствующее рамке, представленной на карте 1.

\section{Epanerchodus lipsae Golovatch et Geoffroy sp.n. Figs 17-20, Map 3.}

HOLOTYPE O (MNHN JC 353), China, Sichuan Prov., Jiang you County, Cave Tian Yin Dong (= Grotte de la Musique Céleste), $104^{\circ} 36,243 \mathrm{E}, 31^{\circ} 45,992 \mathrm{~N}, 543 \mathrm{~m}, 26.08 .2009$, leg. J. Lips (No. 4214).

PARATYPES: $2 \sigma^{7} \sigma^{7}, 12$ ㅇ, 7 juv., 2 fragments (MNHN JC 353), same locality, together with holotype; $60^{7} O^{7}, 1$ \%, 1 juv. (MNHN JC 353), same county, Cave Hei Long Dong (= Grotte du Dragon Noir), $104^{\circ} 37.725 \mathrm{E}, 31^{\circ} 47.758 \mathrm{~N}, 800 \mathrm{~m}, 27.08 .2009$, leg. J. Lips (No. 4223); $1 \mathrm{O}^{7}$ (ZMUM $\rho 2354$ ), same locality, 27.08.2009, leg. J. Lips (No. 4221; 2 Oొ $^{\top}, 8$ OP, 3 juv. (MNHN JC 353), same county, White Dragon Cave (= Grotte du Dragon Blanc, = Bai Long Dong, a completely touristic cave), $104^{\circ} 35.076 \mathrm{E}, 31^{\circ} 47.203 \mathrm{~N}$, ca 570 m, 24.08.2009, leg. J. Lips (No. 4186); 1 ㅇ (ZMUM 02356 ), same locality, 24.08.2009, leg. J. Lips (No. 4192); $2 \sigma^{7} \sigma^{7}, 4$ juv. (MNHN JC 353), same locality, 24.08.2009, leg. J. Lips (No. 4193); $2 \bigcirc^{7} 0^{7}, 2$ OO, 1 juv. (MNHN JC 353), Sichuan Prov., Beichuan County, Cave Xing Yuan Dong, $104^{\circ} 44.700 \mathrm{E}, 31^{\circ} 53.480 \mathrm{~N}$, ca 650 $\mathrm{m}, 17.08 .2006$, leg. J. Lips (No. 2410); 1 क (MNHN JC 353), same county, Cave Yuan Dong (= La grotte du Rocher), 104 ${ }^{\circ} 40.099 \mathrm{E}$ $31^{\circ} 53.738 \mathrm{~N}, 1510 \mathrm{~m}, 18.08 .2004$, leg. J. Lips (No. 1593); $1 \mathrm{O}^{7}, 3$ 우, 1 juv., 1 fragment (MNHN JC 353), same locality, 17.08.2006, leg. J. Lips (No. 2402); 1 O, 2 우 (MNHN JC 353), same county, Cave Gan Liang Dong (= Grotte des Aliments Secs), 104 $4^{\circ} 1.449 \mathrm{E}$, $31^{\circ} 49.658 \mathrm{~N}, 620 \mathrm{~m}, 16.08 .2006$, leg. J. Lips (No. 2373); 3 우 (MNHN JC 353), same county, Cave Lian Yu Dong (= Grotte du Poisson chat), $104^{\circ} 41.91 \mathrm{E}, 31^{\circ} 54.13 \mathrm{~N}, 630 \mathrm{~m}, 15.08 .2004$, leg. J. Lips (No. 1559); 1 + (MNHN JC 353), Sichuan Prov., Hua Jiao Ling County, Cave Yao Wang Di Gong, $104^{\circ} 40.479 \mathrm{E}, 31^{\circ} 53.741 \mathrm{~N}, 1300$ m, 28.07.2009, leg. A. Geneau (No. 4077); 1 (MNHN JC 353), same locality, 28.07.2009, leg. A. Geneau (No. 4077); $20^{7} \sigma^{7}, 1$, 1 , 4 juv. (MNHN JC 353), same locality, 29.07.2009, leg. J. Lips (No. 4080);
$1 \mathrm{O}^{7}, 1$ (MNHN JC 353), same county, Cave Zhang Jia Yan Kou Keng, $104^{\circ} 40.456 \mathrm{E}, 31^{\circ} 54.06 \mathrm{~N}, 1360 \mathrm{~m}, 29.07 .2009$, leg. A. Geneau \& M. Lagrede (No. 4094), $1 \mathrm{O}^{7}, 4$ OP, 2 juv. (MNHN JC 353), $1 \mathrm{O}^{7}, 1$ o (ZMUM 02355 ), same locality, 30.07.2009, leg. J. Lips (No. 4102).

NAME. Gladly dedicated to Josiane Lips, the principal collector of this and many other species of Diplopoda, mainly cavernicolous, in China and elsewhere.

DIAGNOSIS. Differs from congeners by the mostly clearly upturned paraterga, coupled with the presence of a pegshaped exomere, a simple, unciform, subtruncate endomere supplied with two parabasal processes, and sphaerotrichomes on $\sigma^{7}$ postfemora, tibiae and tarsi (see also key in Golovatch [2014a]).

DESCRIPTION. Length of holotype ca $23 \mathrm{~mm}$, width of pro- and metazonae 1.7 and $3.0 \mathrm{~mm}$, respectively; length of $\sigma^{7}$ paratypes ca $22-23 \mathrm{~mm}$, width of pro- and metazonae $1.6-$ 1.8 and $3.0-3.2 \mathrm{~mm}$, respectively; length of $q$ paratypes ca 24-26 mm, width of pro- and metazonae 1.9-2.1 and 3.2-3.5 $\mathrm{mm}$, respectively. Coloration in alcohol uniformly pallid (Figs 17-18). Body with 20 segments. Tegument mainly poorly shining, translucid, texture very delicately alveolate. Head very densely pilose nearly throughout, with squarish genae. Antennae very long and only slightly clavate due to highest antennomere 6 (height measured from the lower to the higher edge) (Figs 17-18), projecting behind segment 4 $\left(\sigma^{7}\right)$ or $3(+)$ when stretched dorsally; antennomere 3 longest, ca 1.2 times as long as subequal antennomeres $4 \& 5$ and ca 1.3 times as long as subequal antennomeres $2 \& 6 ; 5^{\text {th }}$ and $6^{\text {th }}$ each with a small, compact, distodorsal group of bacilliform sensilla; antennomere 7 with a minute dorsoparabasal cone and a distodorsal group of microscopic sensilla. 
In width, head $<$ collum $=$ segments $2-16$, thereafter body gradually tapering towards telson (Figs 17-18). Paraterga strongly developed, set high (at about upper $1 / 4$ of body height), starting from collum; paraterga mostly clearly $\left(\mathrm{O}^{7}\right)$ or only slightly ( $(+)$ upturned above a faintly convex dorsum, drawn clearly forward only on metatergum 2. Collum transversely semilunar, with one faint lateral incision on each side in front of a sharp caudal corner. Caudolateral corner of postcollum paraterga sharp as well, dentiform, increasingly acutangular and drawn behind rear tergal margin, especially strongly extending beyond the margin in segments 17-19; caudal margin of paraterga concave, their front margin forming regularly convex/rounded shoulders,. All poreless segments with three, all pore-bearing ones with four, very faint, setigerous incisions at lateral margin (Figs 17-18). Pore formula normal, ozopores evident, dorsal, located between last and penultimate marginal indentations well off lateral margin. Metatergal sculpture typical, poorly-developed, with three transverse rows of $3+3$ polygonal bosses with setiferous knobs. Sulcus between front and middle rows of setae a little deeper than that between middle and caudal rows. Tergal setae very short, mostly microscopic and largely retained. Stricture between pro- and metazonae wide, shallow and smooth. Limbus very thin, microdenticulate. Pleurosternal carinae absent. Epiproct rather short, conical, pre-apical lateral papillae small. Hypoproct subtrapeziform; caudal, paramedian, setiferous papillae very strong, digitiform, wellseparated.

Sterna without modifications, very poorly setose, crossimpressions shallow. Legs very long and slender, ca 2.3-
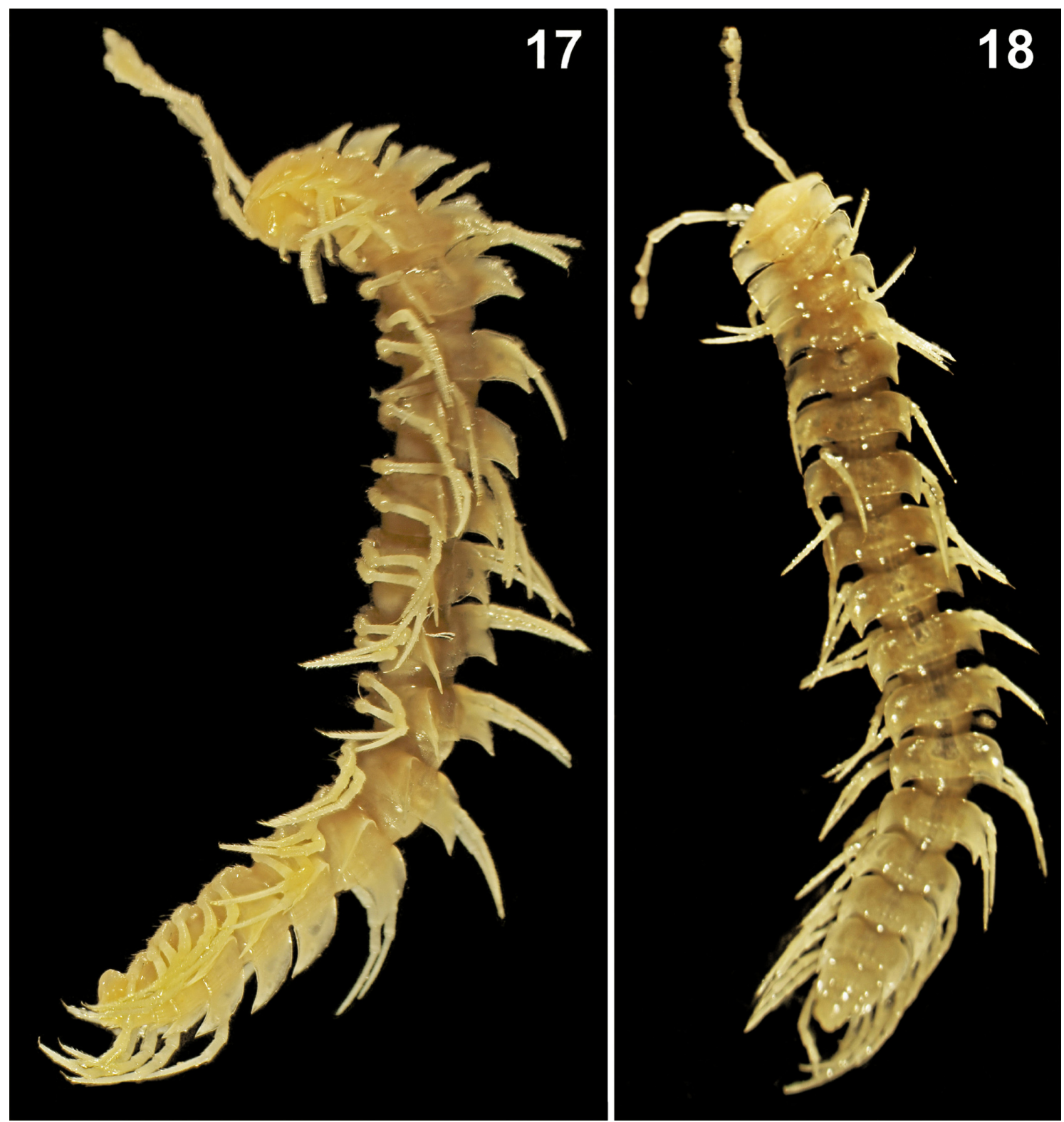

Figs 17-18. Epanerchodus lipsae sp.n., ${ }^{7}$ paratype from Cave Zhang Jia Yan Ku Keng, habitus: 17 — sublateral view; 18 - dorsal view. Photographs by A. Kirejtshuk, taken not to scale.

Рис. 17-18. Epanerchodus lipsae sp.n., паратип О7 из пещеры Zhang Jia Yan Ku Keng, внешний вид: 17 — почти сбоку; 18 сверху. Фотографии А. Кирейчука, без масштаба. 
$2.4\left(O^{7}\right)$ or 1.9-2.0 $(+)$ times as long as body height (Figs 17, $18,20)$, tarsi being longest; $O^{7}$ prefemora slender, not bulging laterally; sparse, short, tri- or bifid setae ventrally on $\sigma^{7}$ prefemora and femora, replaced by sphaerotrichomes on acropodite (Fig. 20).

Gonopods (Fig. 19) rather complex, in situ held parallel to each other; coxae strongly fused medially at base, micropapillate laterally, each coxa carrying two strong setae distodorsally. Telopodite mostly suberect, only its distal $1 / 4$ clearly curved caudally, prefemoral (= densely setose) portion nearly half the length of telopodite, the latter's endomere (en) being ribbon-shaped, subtruncate, unciform and clearly trifid, at base supplied with an axe-shaped mesal process $\mathbf{p} 1$ and a longer, flagelliform, lateral process p2; seminal groove starts running mesally first to distally recurve laterad near base of a peg-shaped exomere (ex) and then basad to enter inside an evident accessory seminal chamber opening up on a rather small hairy pulvillus on lateral face.

REMARKS. Due to the long and slender antennae and legs, as well as an unpigmented body and clearly upturned paraterga, this species seems to be a troglobite.
The large, Central + East Asian genus Epanerchodus Attems, 1901 actually dominates the polydesmid fauna of the eastern Palaearctic, encompassing 70+ species, of which at least 17 are currently known to occur in continental China [Golovatch, 2014a, b]. Together with E. lipsae sp.n., only six are presumed troglobites, all confined to the karsts of southern China (Hubei, Sichuan, Guizhou, Yunnan and Guangxi provinces).

ACKNOWLEDGEMENTS. We are obliged to all relevant collectors involved: Josiane Lips (Villeurbanne, France) and her collaborators, Louis Deharveng and Anne Bedos (both MNHN) and their collaborators, and Arthur Clarke (Tasmania, Australia). In addition, Josiane Lips provided all relevant information concerning the localities she had collected at [Lips, 2005, 2009], whereas Louis Deharveng and Anne Bedos rendered the invaluable help in the preparation of the maps. Aleksandr Kirejtshuk (St. Petersburg, Russia) very skillfully took all pictures. Special thanks go to the MNHN administration for financing the first author's stay in Paris in March and April 2014.

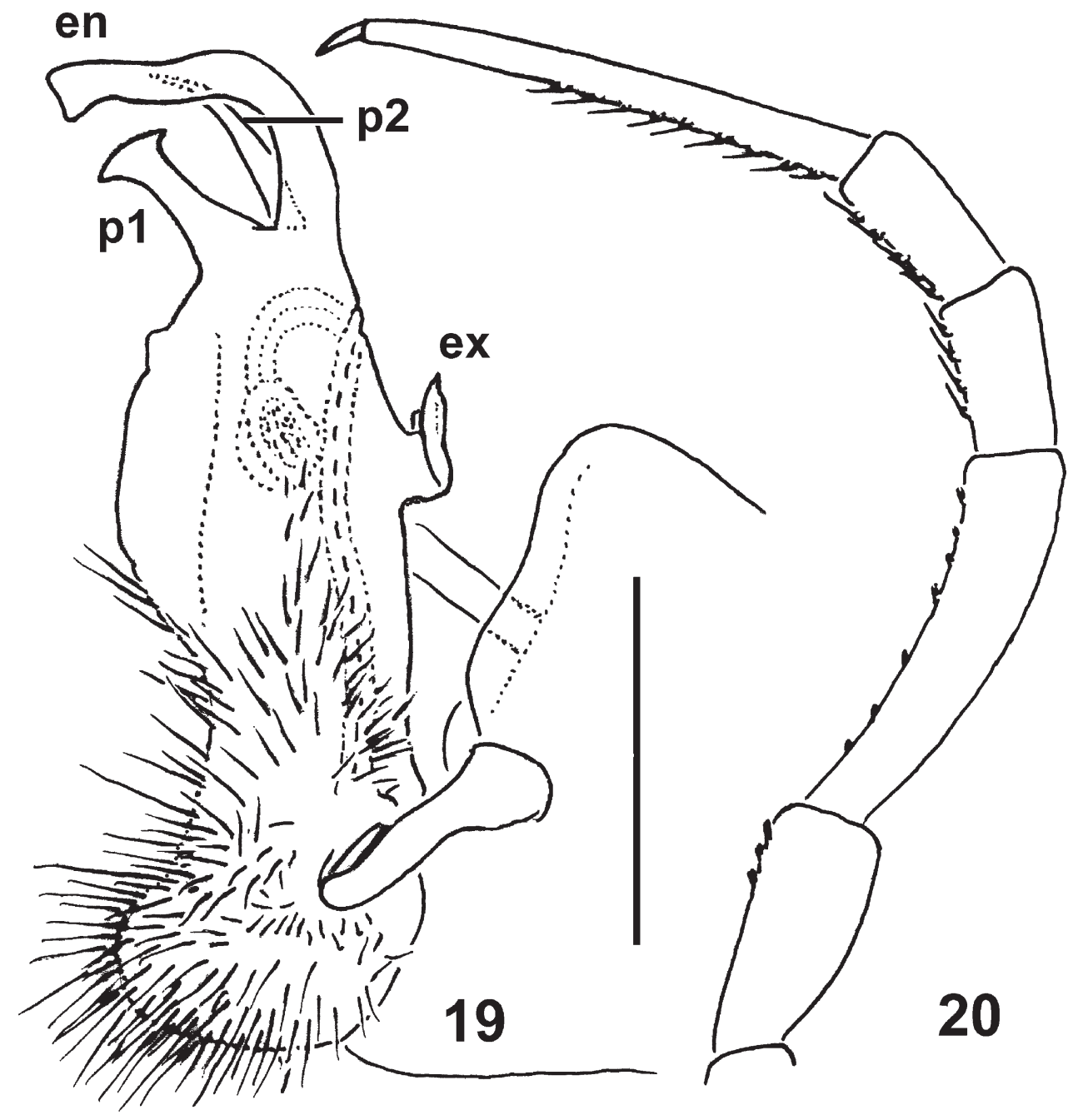

Figs 19-20. Epanerchodus lipsae sp.n., ${ }^{\top}$ paratype from White Dragon Cave: 19 — right gonopod, mesal view; 20 — leg 9, lateral view. Scale bar: $0.3 \mathrm{~mm}$ (19), $0.9 \mathrm{~mm}$ (20). Designations of gonopod structures in text.

Рис. 19-20. Epanerchodus lipsae sp.n., паратип О7 из пещеры White Dragon: 19 — правый гонопод, изнутри; 20 — нога 9, сбоку. Масштаб: 0,3 мм (19), 0,9 мм (20). Обозначения частей гонопода в тексте. 


\section{References}

Geoffroy J.-J., Golovatch S.I. 2004. Some polydesmidan millipedes from caves in southern China (Diplopoda: Polydesmida), with descriptions of four new species // Arthropoda Selecta. Vol.13. Nos 1-2. P.19-28.

Golovatch S.I. 1988. On the first Polydesmidae, Opisotretidae and Fuhrmannodesmidae from Bhutan (Diplopoda, Polydesmida) // Entomologica Basiliensia. Vol.12. P.15-48.

Golovatch S.I. 1991. The millipede family Polydesmidae in Southeast Asia, with notes on phylogeny (Diplopoda: Polydesmida) // Steenstrupia. Vol.17. P.141-159.

Golovatch S.I. 2014a. Review of the millipede genus Epanerchodus Attems, 1901 in continental China, with descriptions of new species (Diplopoda: Polydesmidae) // Zootaxa. Vol.3760. No.2. P.275-288.

Golovatch S.I. 2014b. Two new and one little-known species of the millipede genus Epanerchodus Attems, 1901 from southern China (Diplopoda, Polydesmida, Polydesmidae) // Fragmenta Faunistica. Vol.56. No.2. P.157-166 (for 2013).

Golovatch S.I., Geoffroy J.-J., Mauriès J.-P. 2007. Several new or poorly-known cavernicolous millipedes (Diplopoda) from south- ern China // Arthropoda Selecta. Vol.15. No.2. P.81-89 (for 2006).

Golovatch S.I., Geoffroy J.-J., Mauriès J.-P. 2010. Review of the millipede genus Pacidesmus Golovatch, 1991, with descriptions of three new species from caves in southern China (Diplopoda: Polydesmida: Polydesmidae) // Tropical Natural History. Vol.10. No.2. P.159-169.

Golovatch S.I., Liu W.X., Li Y.B., Geoffroy J.-J. 2012. One new and two little-known species of the millipede family Polydesmidae in southern China (Diplopoda: Polydesmida) // Arthropoda Selecta. Vol.21. No.2. P.131-136.

Lips B. (ed.). 2005. Spéléologie au Pays de l'Homme Sauvage n62004. Rapport de la 6ème expédition spéléologique en Chine A.K.L. 2004 Province du Sichuan // Institut de Technologie de Chengdu, Fédération Française de Spéléologie. 88 pp. http:// www.groupe-speleo-vulcain.com/explorations/expeditions-aletranger/

Lips B. (ed.). 2009. Spéléologie au Pays de l'Homme Sauvage nº2009. Rapport de la 8ème expédition spéléologique en Chine A.K.L. 2009 Provinces de l'Hubei et du Sichuan // Institut de Technologie de Chengdu, Fédération Française de Spéléologie. 112 pp. http://www.groupe-speleo-vulcain.com/explorations/ expeditions-a-letranger/ 